\title{
Food resource partitioning and competition among alvinellid polychaetes of Juan de Fuca Ridge hydrothermal vents
}

\author{
Christian Levesque $^{1, *}$, S. Kim Juniper ${ }^{1}$, Jean Marcus ${ }^{2}$ \\ ${ }^{1}$ Centre GÉOTOP-UQAM-McGill and Département des sciences biologiques, Université du Québec à Montréal, \\ Case Postale 8888, succursale Centre-Ville, Montréal, Québec H3C 3P8, Canada \\ ${ }^{2}$ Department of Biology, University of Victoria, PO Box 3020, Stn CSC, Victoria, British Columbia V8W 3N5, Canada
}

\begin{abstract}
Biotic communities in highly variable, frequently perturbed habitats are usually expected to be structured mainly by abiotic factors. In the highly variable deep-sea hydrothermal vent environment, physical and chemical factors are known to play an important role in limiting the distribution and abundance of species, but the importance of biotic interactions remains largely unresolved. The high density and biomass attained by the vent macrofauna suggest that resource partitioning and competition may be significant in these communities. This study of food resource utilisation at northeast Pacific deep-sea hydrothermal vents uses an approach based on stable carbon and nitrogen isotope analyses to characterise trophic interactions between the 3 dominant alvinellid polychaetes, Paralvinella palmiformis, $P$. sulfincola, and $P$. pandorae. We also examine size structure in sympatric and allopatric populations of $P$. palmiformis and $P$. pandorae. Results indicate that food resource partitioning occurs both intra- and interspecifically in $P$. palmiformis and $P$. sulfincola, and we advocate that this process contributes to explaining their co-existence at very high densities. In contrast, $P$. pandorae has a much more restricted trophic niche, overlaps $P$. palmiformis in diet and is much smaller in size when found in sympatry with $P$. palmiformis. $P$. pandorae is the most likely of the 3 species to be affected by intra- and/or interspecific competition for food, and this may explain the drastic change in the population size structure observed between successive years. Our work indicates that within the limits imposed by environmental conditions, biotic interactions such as food resource partitioning and competition can be significant factors structuring deep-sea hydrothermal vent communities.
\end{abstract}

KEY WORDS: Food partitioning $\cdot$ Competition $\cdot$ Hydrothermal vents $\cdot$ Variable habitats $\cdot$ Alvinellid polychaetes $\cdot$ Stable isotopes

\section{INTRODUCTION}

Biotic communities in highly variable, frequently perturbed habitats are often thought to be structured mainly by abiotic factors (Sanders 1968, Menge \& Sutherland 1976, Lubchenco \& Menge 1978, Peckarsky 1983). Deep-sea hydrothermal vents are stochastic habitats characterised by drastic spatial and temporal heterogeneity in vent fluid temperature and composition (Johnson et al. 1986, 1988, Chevaldonné et al. 1991, Sarrazin et al. 1999). Because of the harsh, vari- able and heterogeneous character of the habitat, it is generally assumed that abiotic factors play a major role in structuring vent communities (Tunnicliffe \& Juniper 1990, Van Dover 1995, Sarrazin et al. 1997). Changes in fluid flow, temperature and chemical composition, mineral accretion and catastrophic perturbations are known to modify species distributions at vents (Tunnicliffe et al. 1985, Tunnicliffe \& Juniper 1990, Chevaldonné et al. 1991, Tunnicliffe 1991, Sarrazin et al. 1997, 1999, Shank et al. 1998, Sarrazin \& Juniper 1999, Luther et al. 2001). In contrast, the importance of bio- 
logical processes such as predation and competition remains poorly understood, partly because they are difficult to study in these remote systems (Tunnicliffe 1991, Mullineaux et al. 1996, Sarrazin et al. 1997, Micheli et al. 2002).

Where organism abundance and biomass are high, density-dependent biotic processes are likely to influence species distribution. Hydrothermal vent faunal biomass is comparable to or higher than that of the most productive marine ecosystems, attaining 10 to $>40 \mathrm{~kg}$ wet weight $\mathrm{m}^{-2}$ (reviewed in Sarrazin \& Juniper 1999). In eastern Pacific hydrothermal vent communities, alvinellid worms (Polychaeta: Terebellidae) form a significant part of this biomass and are dominant members of the consumer fauna (Fustec et al. 1987, Tunnicliffe \& Juniper 1990, Sarrazin \& Juniper 1999). At Juan de Fuca Ridge hydrothermal vents (northeast Pacific), the alvinellids Paralvinella palmiformis Desbruyères \& Laubier 1986 and Paralvinella sulfincola Tunnicliffe et al. 1993 can respectively reach densities of 11000 and 3800 ind. $\mathrm{m}^{-2}$, and biomass values of 4.9 and $0.5 \mathrm{~kg} \mathrm{~m}^{-2}$ of sulphide chimney surface (Sarrazin \& Juniper 1999). Another alvinellid, Paralvinella pandorae Desbruyères \& Laubier 1986, can reach densities of up to 15000 ind. $\mathrm{m}^{-2}$ (Tsurumi 2001) and biomass values of $0.16 \mathrm{~kg} \mathrm{~m}^{-2}$ (J.M. unpubl. data) of vestimentiferan tube surface area, within vestimentiferan tube worm assemblages.

These 3 species of alvinellids are sedentary worms endemic to northeast Pacific hydrothermal vents, where they are among the most abundant organisms. Paralvinella palmiformis occurs on the surface of sulphide mineral deposits or with its caudal end coiled around the distal portion of vestimentiferan tubes (Desbruyères \& Laubier 1986, 1991, Tunnicliffe et al. 1993). P. sulfincola lives in mucous tubes, either on the sulphide mineral substratum or within vestimentiferan bushes (Tunnicliffe et al. 1993, Sarrazin et al. 1999). $P$. palmiformis and P. sulfincola overlap in their habitat and often occur sympatrically (Tunnicliffe et al. 1993, Sarrazin et al. 1997, Sarrazin \& Juniper 1999). They are widely distributed within the northeast Pacific vent environment, co-existing in most sulphide edifice assemblages (Sarrazin \& Juniper 1999). P. pandorae lives primarily in mucous sheaths attached to vestimentiferan tubes (Desbruyères \& Laubier 1986). In vestimentiferan bushes, $P$. palmiformis and $P$. pandorae occupy a similar habitat. Based on an observed size shift of $P$. pandorae following the colonisation by $P$. palmiformis, Tunnicliffe et al. (1997) and Tsurumi \& Tunnicliffe (2001) suggested that these species could be competitors.

When population densities are very high, intra- and interspecific partitioning of resources will promote coexistence by reducing niche overlap and competition
(Schoener 1974, Pianka 1981, Wotton 1990). Mechanisms that allow co-existing organisms to partition trophic and spatial resources among themselves may thus significantly influence community structure and species diversity (Schoener 1974, Pianka 1981).

Despite their high abundance, the food sources of northeast Pacific alvinellid polychaetes have not been clearly identified. Paralvinella palmiformis is likely a suspension and/or deposit feeder (Desbruyères \& Laubier 1986, 1991, Tunnicliffe et al. 1993). P. sulfincola appears to deposit-feed on biofilms colonising its tube and the surrounding sulphide surfaces (Tunnicliffe et al. 1993, Grelon 2001, Morineaux et al. 2003). Both species have a typical detritivorous buccal morphology, presumably for collecting particles with their oral tentacles and trilobate appendages (Chevaldonné 1996). P. pandorae probably also combines depositand suspension-feeding: small oral tentacles collect small particles, while funnel-like branchial structures can collect larger suspended particles (Desbruyères \& Laubier 1991, Chevaldonné 1996). The diets of these 3 species cannot be differentiated by their gut contents, which consists of filamentous bacteria, mucus, diatom debris, grains of sulphide and globules of elemental sulphur (Tunnicliffe et al. 1985, McHugh 1987, Juniper 1994).

For species where visual identification of diet is ineffective, stable carbon and nitrogen isotopes are valuable tools for studying trophic ecology. Stable isotopes of carbon $\left({ }^{13} \mathrm{C} /{ }^{12} \mathrm{C}\right)$ are incorporated in the tissues of heterotrophs with little or no change from their food sources (usually 0 to $1 \%$ fractionation of $\delta^{13} \mathrm{C}$ during trophic transfer; DeNiro \& Epstein 1978, Fry \& Sherr 1989, Wada et al. 1993). Stable isotopes of nitrogen $\left({ }^{15} \mathrm{~N} /{ }^{14} \mathrm{~N}\right)$ are incorporated with a relatively constant trophic shift, with the heavier isotope favoured in consumer tissues $(+3.4 \%$ on average; DeNiro \& Epstein 1981, Minagawa \& Wada 1984, Peterson \& Fry 1987, Cabana \& Rasmussen 1994). Stable carbon and nitrogen isotopic compositions can therefore provide information about resource use by organisms and their relative trophic position (Peterson \& Fry 1987, Kling et al. 1992, Vander Zanden \& Rasmussen 1999). Here we use a stable-isotope-based approach to investigate intra- and interspecific food resource partitioning among the 3 dominant vent polychaete species, Paralvinella palmiformis, $P$. sulfincola and P. pandorae.

\section{MATERIALS AND METHODS}

From 1995 to 2000, 5 cruises were undertaken to hydrothermally active fields on Axial Volcano $\left(45^{\circ} 56^{\prime} \mathrm{N}, 130^{\circ} 00^{\prime} \mathrm{W}\right.$; depth $\sim 1500 \mathrm{~m}$ ) and Endeavour 
Segment $\left(47^{\circ} 57^{\prime} \mathrm{N}, 129^{\circ} 06^{\prime} \mathrm{W}\right.$; depth $\left.\sim 2250 \mathrm{~m}\right)$, Juan de Fuca Ridge, northeast Pacific (Fig. 1).

We investigated 2 major types of vent habitats colonised by Paralvinella palmiformis, $P$. sulfincola and $P$. pandorae. One habitat, sulphide edifices, is formed by metre-scale vertical structures created by the precipitation of minerals from high-temperature (up to $\sim 400^{\circ} \mathrm{C}$ ) hydrothermal fluids. They are colonised by a mosaic of faunal assemblages described by Sarrazin et al. (1997) and Sarrazin \& Juniper (1999). The other habitat, basalt-hosted vents, are patches of metre- to decametre-scale areas on the seafloor where warm $\left(<80^{\circ} \mathrm{C}\right)$ hydrothermal fluids diffuse through the basaltic crust. These sites are frequently colonised by vestimentiferan tube worm assemblages.

From these 2 vent habitats, 10 sites colonised by Paralvinella spp. were selected to reflect the variability in community composition of the region; see Table 1 for site descriptions. Sites A to D were colonised by $P$. palmiformis and P. sulfincola, Sites E and F by P. palmiformis and P. pandorae, and Sites $\mathrm{G}$ and $\mathrm{H}$ by all 3 species. We also sampled one site colonised only by P. palmiformis (Site I) and another colonised only by $P$. pandorae (Site J).

These 10 sites were visited either with the remotely operated vehicle 'ROPOS' or the manned submersible 'Alvin'. Worms were sampled using a suction sampling apparatus pumping water into 21 acrylic jars equipped with 2 layers of $200 \mu \mathrm{m}$ Nitex nylon mesh at the outflow to retain samples, and/or using the hydraulic

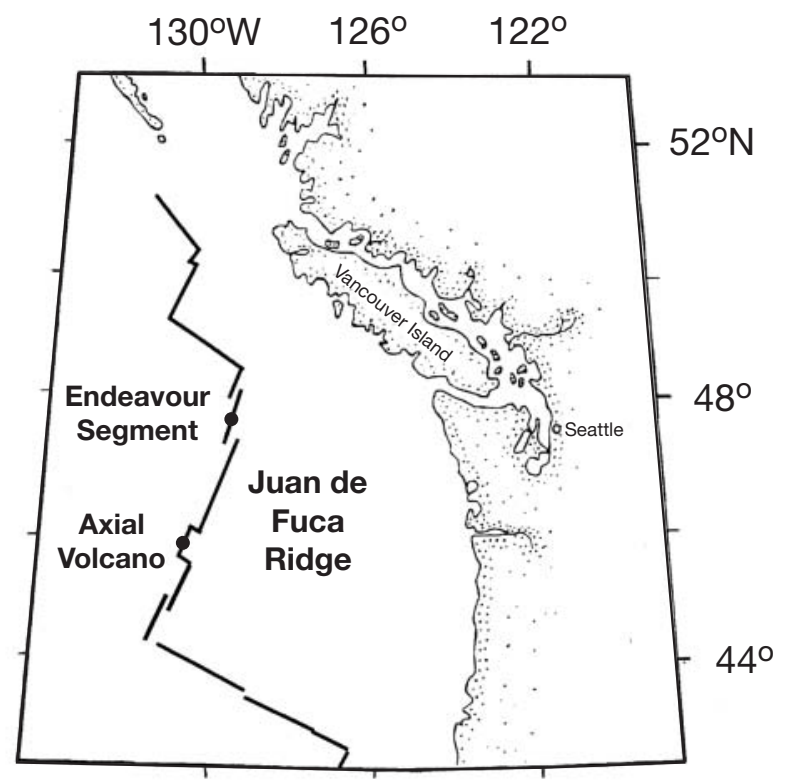

Fig. 1. Location of Axial Volcano and Endeavour Segment, Juan de Fuca Ridge, northeast Pacific Ocean

manipulators of the vehicles to grab tube worm bushes and mineral flanges. Samples were kept in closed boxes or jars at ambient bottom temperature $\left(\sim 2^{\circ} \mathrm{C}\right)$ until they were brought to the surface.

Once onboard, animals were sorted by species and gently rinsed in seawater to remove attached particulates. Samples were frozen at $-80^{\circ} \mathrm{C}$ until analysis. Worms from Site B were preserved in $7 \%$ formalin in seawater. Formalin preservation can affect the stable carbon isotopic composition of biological samples (e.g. Bosley \& Wainright 1999). In other alvinellid samples from the same areas, the 'formalin effect' on $\delta^{13} \mathrm{C}$ amounted to $-1.8 \%$ on average (C.L. unpubl. data). However, in this study, no correction was made for this effect since $\delta^{13} \mathrm{C}$ values were not compared between sites.

In the laboratory, the animals were thawed and wet weighed. Depending upon specimen availability, 2 to 18 individuals per species per site were prepared for stable isotope analyses. The worms were dissected to remove gut contents, their tissues were acidified with $0.1 \mathrm{~N} \mathrm{HCl}$ to remove carbonates and then dried at $60^{\circ} \mathrm{C}$. Dried samples were ground to a fine powder using a mortar and pestle. Stable isotope analyses were performed on an automated Micromass Isoprime isotope ratio mass spectrometer. Carbon and nitro- 
gen stable isotopic ratios were reported on the delta scale:

$$
\delta X=\left[\left(R_{\text {sample }} / R_{\text {standard }}\right)-1\right] \times 1000(\%)
$$

where $X$ is ${ }^{13} \mathrm{C}$ or ${ }^{15} \mathrm{~N}$ and $R$ is ${ }^{13} \mathrm{C} /{ }^{12} \mathrm{C}$ or ${ }^{15} \mathrm{~N} /{ }^{14} \mathrm{~N}$ (Ehleringer \& Rundel 1989). Standards used were Pee-Dee Belemnite (PDB) for carbon and atmospheric $\mathrm{N}_{2}$ for nitrogen.

Spearman's rank correlations between wet weight and $\delta^{13} \mathrm{C}$ and $\delta^{15} \mathrm{~N}$ were calculated for each species at each site. Multivariate analysis of variance (MANOVA) was used to test for interspecific differences in the stable isotopic compositions (both $\delta^{13} \mathrm{C}$ and $\delta^{15} \mathrm{~N}$ ) at each site. When significant $(\mathrm{p}<0.05)$ differences were found, analysis of variance (ANOVA) was used to separately test for interspecific differences in $\delta^{13} \mathrm{C}$ and $\delta^{15} \mathrm{~N}$. Normal distribution was tested by the Shapiro-Wilk's $W$ test, and homogeneity of variances was verified by the Bartlett test. Deviations from normal distribution or homogeneous variances were corrected by log-transforming the data (absolute values were used for $\delta^{13} \mathrm{C}$ ) before performing the parametric tests.

To further document the size structure of Paralvinella pandorae in allopatry and in sympatry with $P$. palmiformis, we examined the wet weight frequency distribution of 100 randomly sub-sampled $P$. pandorae from Nascent Vent (Axial Volcano, South Rift Zone) in allopatry in 1998 and in sympatry with $P$. palmiformis the following year.

\section{RESULTS}

\section{Intraspecific variability}

Intraspecific variability in $\delta^{13} \mathrm{C}$ and $\delta^{15} \mathrm{~N}$ was very high in Paralvinella palmiformis and P. sulfincola compared to $P$. pandorae (Table 2). Large intra-site ranges in isotopic composition were observed in $P$. palmiformis (up to $6.8 \%$ for $\delta^{13} \mathrm{C}$ and $6.6 \%$ for $\delta^{15} \mathrm{~N}$ ) and in P. sulfincola (up to $6.9 \%$ for $\delta^{13} \mathrm{C}$ and $7.4 \%$ for $\delta^{15} \mathrm{~N}$ ). In contrast, the maximum ranges in $\delta^{13} \mathrm{C}$ and $\delta^{15} \mathrm{~N}$ for $P$. pandorae at any given site were 1.0 and $2.2 \%$ respectively (Table 2 ). In comparison, in 10 species from 4 vent sites at Axial Volcano, the species-specific ranges in both $\delta^{13} \mathrm{C}$ and $\delta^{15} \mathrm{~N}$ were typically 2 to $6 \%$ (Levesque et al. unpubl.).

The large intraspecific variability in stable isotopic composition of Paralvinella palmiformis and P. sulfincola was correlated with body size in some cases (Table 3). In P. palmiformis, wet weight correlated significantly $(\mathrm{p}<0.05)$ with $\delta^{13} \mathrm{C}$ and $\delta^{15} \mathrm{~N}$ at 4 out of 9
Table 3. Paralvinella palmiformis, P. sulfincola and P. pandorae. Spearman's rank correlation coefficients between wet weight $(\mathrm{g})$ and $\delta^{13} \mathrm{C}$ and $\delta^{15} \mathrm{~N}$. Significance levels: ${ }^{*} \mathrm{p}<0.05$; ${ }^{* *} p<0.01$. Site abbreviations: see Table 1

\begin{tabular}{|lccc|}
\hline Species & Site & $\delta^{13} \mathrm{C}$ & $\delta^{15} \mathrm{~N}$ \\
\hline P. palmiformis & $\mathrm{A}$ & -0.43 & 0.34 \\
& $\mathrm{~B}$ & $0.67^{*}$ & $0.80^{* *}$ \\
& $\mathrm{C}$ & -0.12 & 0.45 \\
& $\mathrm{D}$ & 0.43 & 0.10 \\
& $\mathrm{E}$ & $-0.62^{*}$ & $0.58^{*}$ \\
& $\mathrm{~F}$ & 0.53 & $0.70^{*}$ \\
& $\mathrm{G}$ & -0.04 & 0.36 \\
& $\mathrm{H}$ & 0.80 & -0.80 \\
& $\mathrm{I}$ & $-0.71^{*}$ & $0.68^{*}$ \\
& $\mathrm{~A}$ & $0.42^{*}$ & -0.22 \\
& $\mathrm{~B}$ & 0.01 & -0.13 \\
& $\mathrm{C}$ & 0.10 & 0.57 \\
& $\mathrm{D}$ & -0.36 & $0.66^{*}$ \\
& $\mathrm{G}$ & $-0.81^{* *}$ & 0.33 \\
& $\mathrm{H}$ & 0.50 & -0.50 \\
& $\mathrm{E}$ & -0.06 & 0.42 \\
& $\mathrm{G}$ & 0.06 & -0.07 \\
& $\mathrm{~J}$ & 0.19 & 0.03 \\
\hline
\end{tabular}

sites. $\delta^{13} \mathrm{C}$ increased with wet weight at Site $\mathrm{B}$, and it showed the opposite trend at Sites $\mathrm{E}$ and I. $\delta^{15} \mathrm{~N}$ increased with wet weight at all 4 sites. $\delta^{13} \mathrm{C}$ and $\delta^{15} \mathrm{~N}$ of $P$. palmiformis also showed strong but not significant 

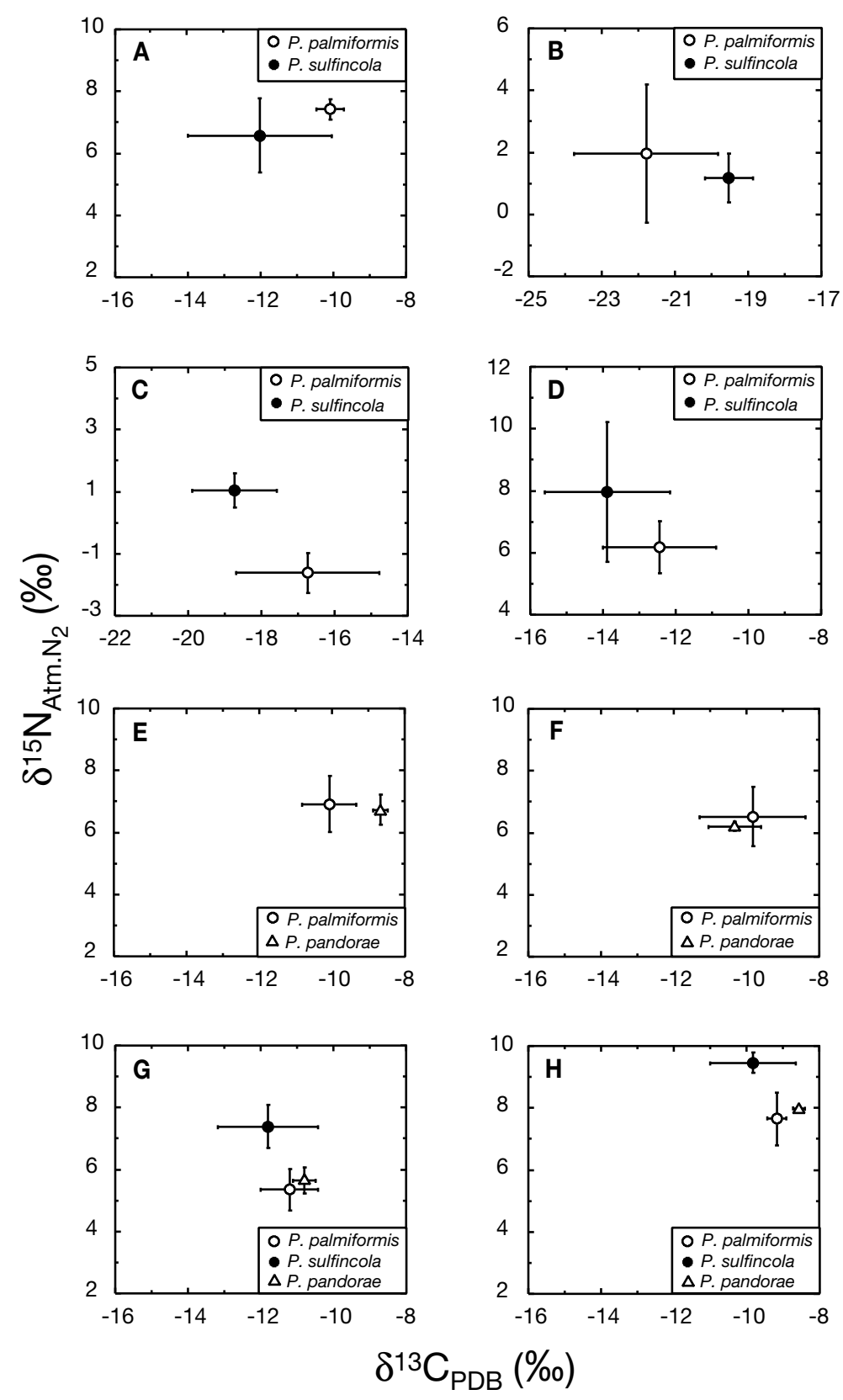

Fig. 2. Paralvinella palmiformis, $P$. sulfincola and $P$. pandorae. Stable carbon $\left(\delta^{13} \mathrm{C}\right)$ and nitrogen $\left(\delta^{15} \mathrm{~N}\right)$ isotopic composition in sympatric assemblages. P. palmiformis and P. sulfincola were present in sympatry at Sites A-D. P. palmiformis and P. pandorae co-occurred at Sites E and F. All 3 species co-existed at Sites G and H. Crosses show mean \pm SD. Site abbreviations: see Table 1 and isotopic composition were observed for P. pandorae.

\section{Interspecific variability}

The stable isotopic signatures of Paralvinella palmiformis and $P$. pandorae were very similar, while $P$. sulfincola differed substantially from the other 2 species (Fig. 2, Table 4).

At both sites where all 3 species occurred (Sites $\mathrm{G}$ and $\mathrm{H}$ ), MANOVA indicated significant differences in the stable isotopic signatures of the species (Wilks's lambda, p < 0.05). For these sites, post-hoc MANOVA (Scheiner 1993) were performed on all possible species pairings to test which species actually differed from each other.

At all 6 sites where they co-occurred, Paralvinella palmiformis and $P$. sulfincola differed significantly in their stable isotopic signatures (MANOVA using $\delta^{13} \mathrm{C}$ and $\delta^{15} \mathrm{~N}, \mathrm{p}<0.05$ in all cases; Fig. 2, Table 4). Analysis of variance (ANOVA) indicated that this was due to differences of 0.6 to $2.7 \%$ in $\delta^{13} \mathrm{C}$ and $\delta^{15} \mathrm{~N}$.

At both sites where they co-occurred, Paralvinella sulfincola and $P$. pandorae showed significant (MANOVA: $\mathrm{p}<0.0001$ ) or marginally significant differences in stable isotopic signatures that resulted from differences in both $\delta^{13} \mathrm{C}$ and $\delta^{15} \mathrm{~N}$ (Fig. 2, Table 4).

In contrast, Paralvinella palmiformis and $P$. pandorae had highly similar $\delta^{13} \mathrm{C}$ and $\delta^{15} \mathrm{~N}$ (Fig. 2, Table 4). At 3 of 4 sites where they cooccurred, these species did not differ significantly in their stable isotopic compositions (MANOVA using $\delta^{13} \mathrm{C}$ and $\delta^{15} \mathrm{~N}$ : $\mathrm{p}>0.05$ in all cases). At the fourth site, they differed in $\delta^{13} \mathrm{C}$ only (ANOVA: $\mathrm{p}<0.0001$ ).

The size structure of Paralvinella pandorae in allopatry and in sympatry with $P$. palmiformis, documented at Nascent Vent, shows a $>14 \times$ reduction in mean wet weight of $P$. pandorae in sympatry (mean wet weight $=3 \mathrm{mg}$ ) compared to allopatry (mean wet weight $=47 \mathrm{mg}$; Fig. 3).

\section{DISCUSSION}

correlations with wet weight at Site H. For $P$. sulfincola, significant correlations were observed only between wet weight and either $\delta^{13} \mathrm{C}$ or $\delta^{15} \mathrm{~N}$ in 3 out of 6 cases: $\delta^{13} \mathrm{C}$ significantly increased with wet weight at Site A, while it decreased with wet weight at Site $G_{\text {; }}$ $\delta^{15} \mathrm{~N}$ was positively correlated with wet weight at Site D. No significant correlations between wet weight

\section{Interpretation of stable isotopic compositions}

When comparing the isotopic compositions of different individuals or different species, one must consider 3 points. First, if 2 organisms use the same dietary car- 
Table 4. Paralvinella palmiformis, P. sulfincola and P. pandorae. Results from comparisons of the stable isotopic compositions of all species pairings: p-values from MANOVAs (using both $\delta^{13} \mathrm{C}$ and $\left.\delta^{15} \mathrm{~N}\right), \delta^{13} \mathrm{C}$ mean difference and $\delta^{15} \mathrm{~N}$ mean difference. When MANOVA indicated significant differences ( $p<0.05$, bold type), ANOVA was performed on $\delta^{13} \mathrm{C}$ and $\delta^{15} \mathrm{~N}$ separately (see text). Significance levels for ANOVAs: ${ }^{*} p<0.05 ;{ }^{* *} p<0.01 ;{ }^{* * *} p<0.0001 ;{ }^{N S}$ not significant. Site abbreviations: see Table 1

\begin{tabular}{|c|c|c|c|}
\hline Site & $\begin{array}{c}\mathrm{p} \text {-value } \\
\text { (MANOVA) }\end{array}$ & $\begin{array}{l}\delta^{13} \mathrm{C} \text { mean } \\
\text { difference }\end{array}$ & $\begin{array}{l}\delta^{15} \mathrm{~N} \text { mean } \\
\text { difference }\end{array}$ \\
\hline \multicolumn{4}{|c|}{ P. palmiformis-P. sulfincola } \\
\hline A & $\mathrm{p}<0.0001$ & $1.93^{* * *}$ & $0.85^{* *}$ \\
\hline $\mathrm{B}$ & $p=0.0032$ & $-2.26^{* *}$ & $0.78^{\mathrm{NS}}$ \\
\hline $\mathrm{C}$ & $\mathrm{p}<0.0001$ & $2.00^{*}$ & $2.65^{* * *}$ \\
\hline $\mathrm{D}$ & $p=0.0176$ & $1.44^{\mathrm{NS}}$ & $-1.78^{\mathrm{NS}}$ \\
\hline $\mathrm{G}$ & $\mathrm{p}<0.0001$ & $0.59^{\mathrm{NS}}$ & $-2.04^{* * *}$ \\
\hline $\mathrm{H}$ & $\mathrm{p}=\mathbf{0 . 0 2 5 3}$ & $0.60^{\mathrm{NS}}$ & $-1.89^{*}$ \\
\hline \multicolumn{4}{|c|}{ P. palmiformis-P. pandorae } \\
\hline E & $\mathrm{p}<0.0001$ & $-1.42^{* * *}$ & $0.19^{\mathrm{NS}}$ \\
\hline $\mathrm{F}$ & $p=0.5932$ & 0.49 & 0.31 \\
\hline $\mathrm{G}$ & $\mathrm{p}=0.4291$ & -0.41 & -0.29 \\
\hline $\mathrm{H}$ & $\mathrm{p}=0.5378$ & -0.60 & -0.41 \\
\hline \multicolumn{4}{|c|}{$P$. pandorae- $P$. sulfincola } \\
\hline $\mathrm{G}$ & $\mathrm{p}<0.0001$ & $1.00^{*}$ & $-1.75^{* * *}$ \\
\hline $\mathrm{H}$ & $\mathrm{p}=0.0529^{\mathrm{a}}$ & $1.20^{\mathrm{NS}}$ & $-1.47^{*}$ \\
\hline
\end{tabular}

bon and nitrogen sources (hereafter 'diet'), they will have similar isotopic compositions. Second, organisms having the same isotopic compositions do not necessarily have the same diet, since they can have different diets with the same averaged isotopic compositions. Third, a difference in the isotopic compositions of 2 organisms reflects a difference in their diets. Stable isotopic compositions can therefore provide information on food resource use and partitioning, both interspecifically and intraspecifically.

The niche breadth of populations has 2 fundamental aspects (Van Valen 1965, Pianka 1981, Polis 1984): the within-individual component (the variation in resources used by an individual) and the betweenindividual component (the variation in resources used by different individuals of a population). One-time sacrificial isotope analysis only provides information on the average diets of individuals within a population. Therefore, the range of stable isotope signatures from individual organisms provides a measure of the between-individual trophic niche breadth of a population.

\section{Intra- and interspecific food resource partitioning}

The large intraspecific variability in the stable isotopic compositions of Paralvinella palmiformis and $P$. sulfincola at each site suggests that these species are trophic generalists compared to the more trophically specialised $P$. pandorae. Indeed, the large variability in $\delta^{13} \mathrm{C}$ and $\delta^{15} \mathrm{~N}$ between individuals of $P$. palmiformis and $P$. sulfincola indicate that different individuals consume different food sources. In contrast, all $P$. pandorae individuals have similar $\delta^{13} \mathrm{C}$ and $\delta^{15} \mathrm{~N}$, indicating they are either using similar food sources or different food sources with similar averaged isotopic compositions. The large variability in stable isotopic compositions of $P$. palmiformis and $P$. sulfincola reveals that the available food sources in these habitats have a large range in $\delta^{13} \mathrm{C}$ and $\delta^{15} \mathrm{~N}$. It is therefore unlikely that at all sites individual $P$. pandorae are consuming different foods with similar $\delta^{13} \mathrm{C}$ and $\delta^{15} \mathrm{~N}$. Thus, we argue that the small ranges in $\delta^{13} \mathrm{C}$ and $\delta^{15} \mathrm{~N}$ in $P$. pandorae indicate that this species is more trophically specialised than P. palmiformis and P. sulfincola.

The large trophic niche width of Paralvinella palmiformis could be explained by ontogenetic shifts in diet. Significant correlations between wet weight and tis-

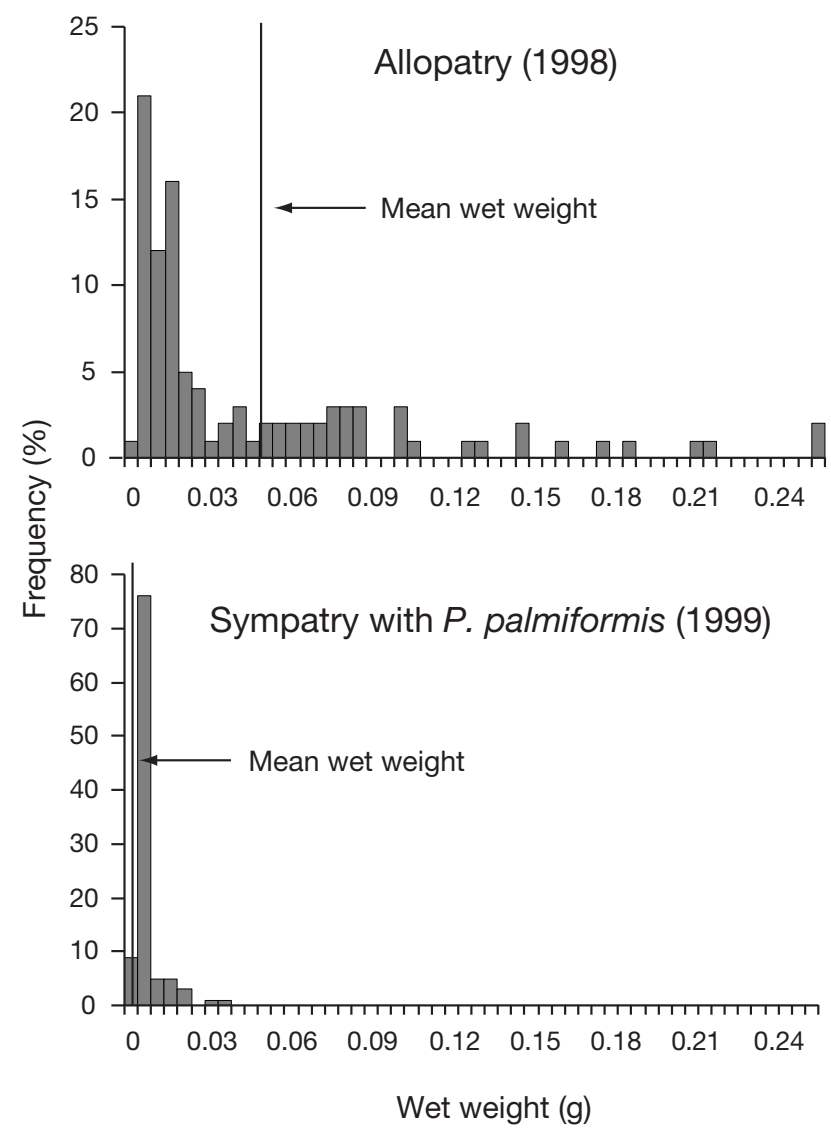

Fig. 3. Paralvinella pandorae. Wet weight frequency distribution in allopatry (Nascent Vent, 1998) and in sympatry with $P$. palmiformis (Nascent Vent, 1999). Mean wet weight of $P$. pandorae is $14 \times$ smaller in sympatry compared to allopatry. Notice the different vertical scales 
sue stable isotopic composition indicate size-related changes in isotopic signature of $P$. palmiformis at 4 different sites (Table 3). Because the isotopic composition of an animal reflects that of its diet, such correlations can indicate size-dependent shifts in diet (e.g. Gearing et al. 1984, Michener \& Schell 1994, Hentschel 1998, Polz et al. 1998, Trask \& Van Dover 1999). It remains unclear why size-related changes in the stable isotopic signature of $P$. palmiformis were observed at only 4 out of 9 sites. This could reflect our inability to sample juveniles and small size classes, where most ontogenetic diet shifts may occur (e.g. Hentschel 1998). Because juveniles and very small individuals were not sampled here, our results may under-estimate the trophic niche width of the species investigated and miss critical changes in their trophic ecology. In this regard, possible ontogenetic diet changes in Paralvinella spp. should be re-examined after a more representative sampling of their complete size ranges.

In Paralvinella sulfincola, diet was not related to size as clearly as in P. palmiformis, within the size range sampled. A more probable explanation of the large trophic niche observed in P. sulfincola could be its territorial behaviour described by Grelon (2001). This species aggressively interferes with neighbouring conspecifics, and thus it maintains a regular micro-distribution on the substratum. Territoriality, reflecting interference competition, constrains individual feeding areas and accessible food resources. A consequence of individual $P$. sulfincola feeding at different locations, presumably on different food sources, would be a broad range in stable carbon and nitrogen isotope compositions such as observed here.

Stable isotopic compositions also provide information on interspecific food resource partitioning. Despite the large intraspecific variability in $\delta^{13} \mathrm{C}$ and $\delta^{15} \mathrm{~N}$, the stable isotopic compositions of Paralvinella palmiformis and $P$. sulfincola were different at all 6 sites where they co-occurred, clearly indicating interspecific differences in food resource use. The lack of constancy in these differences $\left(\delta^{13} \mathrm{C}\right.$ and $\delta^{15} \mathrm{~N}$ values were either higher or lower in P. palmiformis compared to P. sulfincola) suggest they are not the result of interspecific differences in isotopic fractionation, but rather reflect the use of different trophic resources.

Differences in feeding modes of Paralvinella palmiformis and $P$. sulfincola may contribute to interspecific food resource partitioning. The former is usually considered as a deposit- and/or suspension-feeder (Desbruyères \& Laubier 1986, 1991, Tunnicliffe et al. 1993), while $P$. sulfincola has only been observed depositfeeding (Tunnicliffe et al. 1993, Grelon 2001, Morineaux et al. 2003). Suspension-feeding could give P. palmiformis access to food resources not consumed by $P$. sulfincola. However, the feeding behaviour of these species, particularly within tube worm bushes, remains too poorly characterised to evaluate whether and how differences in feeding behaviour affect diet.

Behaviour may contribute in another way to food resource partitioning between Paralvinella palmiformis and P. sulfincola. On the mineral surface of chimneys, these species often show a distinct micro-distribution: $P$. sulfincola colonise the background substratum and P. palmiformis group on small marcasite $\left(\mathrm{FeS}_{2}\right)$ outgrowths (Sarrazin et al. 1997). Spatial partitioning may also occur as vertical zonation in tube worm bushes, where $P$. sulfincola is often observed on the hard substratum while $P$. palmiformis attaches to vestimentiferan tubes (J. Sarrazin, IFREMER, Centre de Brest, France, pers. comm.). This spatial segregation may restrict where the 2 species feed and thus their food resources.

Filamentous bacteria growing on Paralvinella sulfincola mucous tubes may also provide an exclusive food source to this alvinellid. A similar association has been proposed between the East-Pacific Rise alvinellid Alvinella pompejana and the large filamentous bacteria colonising its dorsal surface, but this relationship remains hypothetical (Desbruyères et al. 1998).

\section{Dietary overlap and competition in Paralvinella pandorae and P. palmiformis}

In contrast to co-existing Paralvinella palmiformis and $P$. sulfincola, sympatric $P$. palmiformis and $P$. pandorae have very similar stable isotopic compositions (Fig. 2, Table 4). Their overlapping $\delta^{13} \mathrm{C}$ and $\delta^{15} \mathrm{~N}$ values indicate they are using either similar food sources or different food sources with similar averaged isotopic compositions. The second interpretation would require that the food sources consumed by these 2 species had similar averaged $\delta^{13} \mathrm{C}$ and $\delta^{15} \mathrm{~N}$ at all sites investigated. As discussed above, the large variability in stable isotopic compositions of $P$. palmiformis and $P$. sulfincola indicates that available food sources in these habitats have a large range in $\delta^{13} \mathrm{C}$ and $\delta^{15} \mathrm{~N}$. It is thus unlikely that 2 species feeding on different food sources would have such similar $\delta^{13} \mathrm{C}$ and $\delta^{15} \mathrm{~N}$ at 4 different sites. We suggest therefore that sympatric P. palmiformis and P. pandorae overlap in their trophic niches and are potential competitors.

Dietary overlap does not necessarily lead to exploitative competition unless food resources are limiting (Pianka 1981, MacNally 1983). Whether deep-sea hydrothermal vent deposit- and suspension-feeders can be food limited remains unknown. A large body of evidence suggests that natural populations of macrofaunal deposit-feeders are commonly food limited (Lopez \& Levinton 1987 and references therein). Sedentary deposit-feeders are often limited by trophic resources because they have a restricted ability to actively forage 
and depend on their immediate surroundings for food (Karrh \& Miller 1994).

Compelling evidence further supporting the hypothesis of competition for food actively occurring between Paralvinella palmiformis and P. pandorae comes from the size shift towards smaller size classes in the latter species in sympatry with $P$. palmiformis, documented in this study as well as in Tunnicliffe et al. (1997) and Tsurumi \& Tunnicliffe (2001). This change represents mortality or emigration of larger $P$. pandorae that are comparable in size to P. palmiformis (C.L. pers. obs.). This size shift between allopatry and sympatry may be interpreted as a response to interspecific competition (Pianka 1981), although other factors such as habitat differences could also be involved. We propose that the dietary niche overlap and the size shift of $P$. pandorae between allopatry and sympatry with $P$. palmiformis are evidence that interspecific competition for food is occurring between these species and that $P$. pandorae populations are strongly affected by this process.

It is possible that intraspecific competition could be involved in the observed size shift. The narrow trophic niche of Paralvinella pandorae suggests that intraspecific competition is more likely to affect this species than $P$. palmiformis and P. sulfincola. Consumption of a similar food source by all $P$. pandorae individuals could lead to resource depletion and intraspecific competition. Colonisation by P. palmiformis likely further reduces food resources available for P. pandorae, since both species overlap in their diet. Therefore, the size shift of $P$. pandorae could result from both intraspecific and interspecific competition for food.

Our data do not allow us to verify whether or not competition can affect the distribution and abundance of Paralvinella pandorae. In a study of the faunal assemblages at 14 sites on Cleft segment, Juan de Fuca Ridge, following their initiation by a volcanic eruption in 1986, Tsurumi \& Tunnicliffe (2001) observed drastic shifts in the distribution of $P$. pandorae. Over $2 \mathrm{yr}$, the authors observed a reduction in the number of sites colonised by $P$. pandorae, from 14 sites to 1 site, concomitant with a decrease in body size of $P$. pandorae. Tsurumi \& Tunnicliffe (2001) suggest that the cause of this decrease in site occupation and body size could involve competition with P. palmiformis or the ampharetid polychaete Amphysamytha cf. galapagensis Zottoli, 1983, which shares a similar habitat on vestimentiferan tubes. Thus, competition could affect not only the size structure of $P$. pandorae, but also its distribution. Future studies combining stable isotope analyses with observations on the distribution, abundance and population size structure of $P$. palmiformis, $P$. pandorae and other potential competitors may provide further insight into how competition affects the distribution and abundance of these species. Environmental factors should also be considered in these studies to ensure that the observed shifts in size and distribution are not the result of habitat changes.

Competition has never been clearly demonstrated at vents, and its role in structuring vent communities remains largely unexplored. Interspecific competition for space and for hydrogen sulphide has been suggested to account for changes in the abundance of vestimentiferans, mussels and clams at a Galapagos Rift vent field (Hessler et al. 1988, Johnson et al. 1988). Shank et al. (1998) advanced that a similar competitive process might occur during the development of biological communities at $9^{\circ} 50^{\prime} \mathrm{N}$ on the East Pacific Rise. As discussed above, Tunnicliffe et al. (1997) and Tsurumi \& Tunnicliffe (2001) suggested that Paralvinella pandorae could be competing with $P$. palmiformis and Amphysamytha cf. galapagensis. The present study brings evidence that intraspecific competition for food and/or interspecific competition for food with P. palmiformis are affecting the population size structure of $P$. pandorae at northeast Pacific hydrothermal vents. To our knowledge, this is one of the best developed cases to date for competition at deep-sea hydrothermal vents. These observations provide evidence that competition can be a significant process affecting the structure and dynamics of biological communities in the highly variable hydrothermal vent habitat.

\section{CONCLUSION}

The results presented here indicate that trophic interactions play a significant role in structuring the high-density sympatric alvinellid populations of northeast Pacific hydrothermal vents. Intra- and interspecific resource partitioning in Paralvinella palmiformis and $P$. sulfincola reduce the overlap in resource use between individuals and between species. We advocate that resource partitioning allows these 2 species to co-exist in most communities where they frequently dominate in abundance and biomass. In contrast, $P$. pandorae appears to be a trophic specialist, and its diet overlaps with that of $P$. palmiformis. Intraspecific competition and/or interspecific competition with P. palmiformis appear to result in a marked size reduction in $P$. pandorae in sympatry with $P$. palmiformis. Further studies are required to confirm that competition is actively occurring and to understand its importance for the distribution and abundance of these species. We conclude that intra- and interspecific food resource partitioning and competition for food among the dominant alvinellid polychaetes at northeast Pacific vents should be regarded as significant community structuring factors in these highly variable habitats. 
Acknowledgements. The authors wish to acknowledge the crews of the RV 'TG Thompson', RV 'RH Brown', RV 'Atlantis II' and CGS 'JP Tully', as well as the 'ROPOS' and 'Alvin' teams for their field support. This work benefited from collaborations with investigators of the New Millennium Observatory project (NOAA). We thank Dr Verena Tunnicliffe and 2 anonymous reviewers for their constructive inputs during preparation of this manuscript. This research was sponsored by the Natural Sciences and Engineering Research Council of Canada (NSERC) and the Fonds québécois de la recherche sur la nature et les technologies (FCAR). C.L. was supported by post-graduate scholarships from NSERC, FCAR and Fisheries and Oceans Canada. J.M. was supported by postgraduate scholarships from NSERC, the Canadian Association of University Teachers and the University of Victoria.

\section{LITERATURE CITED}

Bosley KL, Wainright SC (1999) Effects of preservatives and acidification on the stable isotope ratios $\left({ }^{15} \mathrm{~N}:{ }^{14} \mathrm{~N},{ }^{13} \mathrm{C}:{ }^{12} \mathrm{C}\right)$ of two species of marine animals. Can J Fish Aquat Sci 56: $2181-2185$

Cabana G, Rasmussen JB (1994) Modelling food chain structure and contaminant bioaccumulation using stable nitrogen isotopes. Nature 372:255-257

Chevaldonné P (1996) Écologie des cheminées hydrothermales actives. PhD thesis, Centre Océanologique de Marseille

Chevaldonné $P$, Desbruyères D, Le Haître M (1991) Timeseries of temperature from three deep-sea hydrothermal vent sites. Deep-Sea Res 38:1417-1430

DeNiro MJ, Epstein S (1978) Influence of diet on the distribution of carbon isotopes in animals. Geochim Cosmochim Acta 42:495-506

DeNiro MJ, Epstein S (1981) Influence of diet on the distribution of nitrogen isotopes in animals. Geochim Cosmochim Acta 45:341-351

Desbruyères D, Laubier L (1986) Les Alvinellidae, une famille nouvelle d'annélides polychètes inféodés aux sources hydrothermales sous-marines: systématique, biologie et écologie. Can J Zool 64:2227-2245

Desbruyères D, Laubier L (1991) Systematics, phylogeny, ecology and distribution of the Alvinellidae (Polychaeta) from deep-sea hydrothermal vents. Ophelia Suppl 5:31-45

Desbruyères D, Chevaldonné $\mathrm{P}$, Alayse AM, Jollivet D and 14 others (1998) Biology and ecology of the 'Pompei worm' (Alvinella pompejana Desbruyères and Laubier), a normal dweller of an extreme deep-sea environment: a synthesis of current knowledge and recent developments. DeepSea Res II 45:383-422

Ehleringer JR, Rundel PW (1989) Stable isotopes: history, units and instrumentation. In: Rundel PW, Ehleringer JR, Nagy KA (eds) Stable isotopes in ecological research. Springer-Verlag, New York, p 1-15

Fry B, Sherr EB (1989) $\delta^{13} \mathrm{C}$ measurements as indicators of carbon flow in marine and freshwater ecosystems. In: Rundel PW, Ehleringer JR, Nagy KA (eds) Stable isotopes in ecological research. Springer-Verlag, New York, p 197-229

Fustec AD, Desbruyères D, Juniper SK (1987) Deep-sea hydrothermal vent communities at $13^{\circ} \mathrm{N}$ on the east Pacific rise: microdistribution and temporal variations. Biol Oceanogr 4(2):121-164

Gearing JN, Gearing PJ, Rudnick DT, Requejo AG, Hutchins MJ (1984) Isotopic variability of organic carbon in a phytoplankton-based, temperate estuary. Geochim Cosmochim Acta 48:1089-1098
Grelon D (2001) Ecologie et éthologie de Paralvinella sulfincola, polychète des sources hydrothermales profondes du Pacifique nord-est. MSc thesis, Université du Québec à Rimouski

Hentschel BT (1998) Intraspecific variations in $\delta^{13} \mathrm{C}$ indicate ontogenetic diet changes in deposit-feeding polychaetes. Ecology 79:1357-1370

Hessler RR, Smithey WM, Boudrias MA, Keller CH, Lutz RA, Childress JJ (1988) Temporal changes in megafauna at the Rose Garden hydrothermal vent (Galapagos Rift; eastern tropical Pacific). Deep-Sea Res 35:1681-1709

Johnson KS, Beehler CL, Sakamoto-Arnold CM, Childress JJ (1986) In situ measurements of chemical distributions in a deep-sea hydrothermal vent field. Science 231:1139-1141

Johnson KS, Childress JJ, Hessler RR, Sakamoto-Arnold CM, Beehler CL (1988) Chemical and biological interactions in the Rose Garden hydrothermal vent field, Galapagos spreading center. Deep-Sea Res 35:1723-1744

Juniper SK (1994) Ecology and biogeochemistry of Paralvinella sulfincola at northeast Pacific hydrothermal vents: review and comparison with Alvinella spp. of the East Pacific Rise. In: Dauvin JC, Laubier L, Reish DJ (eds) Actes de la $4{ }^{\text {ème }}$ conférence internationale des Polychètes. Mém Mus Natl Hist Nat 162:453-462

Karrh RR, Miller DC (1994) Functional response of a surface deposit feeder, Saccoglossus kowalevskii. Limnol Oceanogr 39:1455-1464

Kling GW, Fry B, O'Brien WJ (1992) Stable isotopes and planktonic trophic structure in arctic lakes. Ecology 73: 561-566

Lopez GR, Levinton JS (1987) Ecology of deposit-feeding animals in marine sediments. Q Rev Biol 62:235-260

Lubchenco J, Menge BA (1978) Community development and persistence in a low rocky intertidal zone. Ecol Monogr 59: $67-94$

Luther GW III, Rozan TF, Taillefert M, Nuzzio DB, Di Meo C, Shank TM, Lutz RA, Cary SC (2001) Chemical speciation drives hydrothermal vent ecology. Nature 410:813-816

MacNally RC (1983) On assessing the significance of interspecific competition to guild structure. Ecology 64: 1646-1652

McHugh D (1987) The life-history patterns of two hydrothermal vent polychaetes, Paralvinella pandorae Desbruyères and Laubier and Paralvinella palmiformis Desbruyères and Laubier. MSc thesis, University of Victoria, BC

Menge BA, Sutherland JP (1976) Species diversity gradients: synthesis of the roles of predation, competition, and temporal heterogeneity. Am Nat 110:351-369

Micheli F, Peterson CH, Mullineaux LS, Fisher CR, Mills SW, Sancho G, Johnson GA, Lenihan HS (2002) Predation structures communities at deep-sea hydrothermal vents. Ecol Monogr 72:365-382

Michener RH, Schell DM (1994) Stable isotope ratios as tracers in marine aquatic food webs. In: Lajtha K, Michener RH (eds) Stable isotopes in ecology and environmental science. Blackwell Scientific Publications, Boston, p 138-157

Minagawa M, Wada E (1984) Stepwise enrichment of ${ }^{15} \mathrm{~N}$ along food chains: further evidence and the relation between $\delta^{15} \mathrm{~N}$ and animal age. Geochim Cosmochim Acta 48:1135-1140

Morineaux M, Grelon D, Juniper SK (2003) Utilization of nutritional resources and energy budgets of the hydrothermal vent polychaete Paralvinella sulfincola on Axial Volcano, Juan de Fuca Ridge (Northeast Pacific). Cah Biol Mar (in press)

Mullineaux LS, Peterson CH, Fisher CR (1996) Colonization of 
hydrothermal vents near $9^{\circ} 50^{\prime} \mathrm{N}$, East Pacific Rise: a cruise report from block party 1, 2 \& 3 . InterRidge News, Vol 5(2). InterRidge Office, Université Pierre et Marie Curie, Paris, p 19-21

Peckarsky BL (1983) Biotic interactions or abiotic limitations? A model of lotic community structure. In: Fontaine TD, Bartell SM (eds) Dynamics of lotic ecosystems. Ann Arbor Science Publishers, Ann Arbor, MI, p 303-323

Peterson BJ, Fry B (1987) Stable isotopes in ecosystem studies. Annu Rev Ecol Syst 18:293-320

Pianka ER (1981) Competition and niche theory. In: May RM (ed) Theoretical ecology: principles and applications, 2nd edn. Sinauer Associates, Sunderland, MA, p 167-196

Polis GA (1984) Age structure component of niche width and intraspecific resource partitioning: can age groups function as ecological species? Am Nat 123:541-564

Polz MF, Robinson JJ, Cavanaugh CM, Van Dover CL (1998) Trophic ecology of massive shrimp aggregations at a MidAtlantic Ridge hydrothermal site. Limnol Oceanogr 43: 1631-1638

Sanders HL (1968) Marine benthic diversity: a comparative study. Am Nat 102:243-282

Sarrazin J, Juniper SK (1999) Biological characteristics of a hydrothermal edifice mosaic community. Mar Ecol Prog Ser 185:1-19

Sarrazin J, Robigou V, Juniper SK, Delaney JR (1997) Biological and geological dynamics over four years on a hightemperature sulfide structure at the Juan de Fuca Ridge hydrothermal observatory. Mar Ecol Prog Ser 153:5-24

Sarrazin J, Juniper SK, Massoth G, Legendre P (1999) Physical and chemical factors influencing species distributions on hydrothermal sulfide edifices of the Juan de Fuca Ridge, northeast Pacific. Mar Ecol Prog Ser 190:89-112

Scheiner SM (1993) MANOVA: multiple response variables and multispecies interactions. In: Scheiner SM, Gurevitch $\mathrm{J}$ (eds) Design and analysis of ecological experiments. Chapman \& Hall, Toronto, p 94-112

Schoener TW (1974) Resource partitioning in ecological communities. Science 185:27-39

Shank TM, Fornari DJ, Von Damm KL, Lilley MD, Haymon RM, Lutz RA (1998) Temporal and spatial patterns of biological community development at nascent deep-sea hydrothermal vents $\left(9^{\circ} 50^{\prime} \mathrm{N}\right.$, East Pacific Rise). Deep-Sea Res II 45:465-515

Trask JL, Van Dover CL (1999) Site-specific and ontogenetic variations in nutrition of mussels (Bathymodiolus sp.) from

Editorial responsibility: Otto Kinne (Editor),

Oldendorf/Luhe, Germany the Lucky Strike hydrothermal vent field, Mid-Atlantic Ridge. Limnol Oceanogr 44:334-343

Tsurumi M (2001) Ecology of hydrothermal vents on three segments of the Juan de Fuca Ridge, northeast Pacific. PhD thesis, University of Victoria, BC

Tsurumi M, Tunnicliffe V (2001) Characteristics of a hydrothermal vent assemblage on a volcanically active segment of Juan de Fuca Ridge, northeast Pacific. Can J Fish Aquat Sci 58:530-542

Tunnicliffe V (1991) The biology of hydrothermal vents: ecology and evolution. Oceanogr Mar Biol Annu Rev 29: $319-407$

Tunnicliffe V, Juniper SK (1990) Dynamic character of the hydrothermal vent habitat and the nature of sulphide chimney fauna. Prog Oceanogr 24:1-13

Tunnicliffe V, Juniper SK, De Burgh ME (1985) The hydrothermal vent community on Axial Seamount, Juan de Fuca Ridge. Bull Biol Soc Wash 6:453-464

Tunnicliffe V, Desbruyères D, Jollivet D, Laubier L (1993) Systematic and ecological characteristics of Paralvinella sulfincola Desbruyères and Laubier, a new polychaete (family Alvinellidae) from northeast Pacific hydrothermal vents. Can J Zool 71:286-297

Tunnicliffe V, Embley RW, Holden JF, Butterfield DA, Massoth GJ, Juniper SK (1997) Biological colonization of new hydrothermal vents following an eruption on Juan de Fuca Ridge. Deep-Sea Res I 44:1627-1644

Vander Zanden MJ, Rasmussen JB (1999) Primary consumer $\delta^{13} \mathrm{C}$ and $\delta^{15} \mathrm{~N}$ and the trophic position of aquatic consumers. Ecology 80:1395-1404

Van Dover CL (1995) Ecology of Mid-Atlantic Ridge hydrothermal vents. In: Parson LM, Walker CL, Dixon DR (eds) Hydrothermal vents and processes. Geol Soc Spec Publ 87:257-294

Van Valen L (1965) Morphological variation and the width of the ecological niche. Am Nat 100:377-389

Wada E, Kabaya Y, Kurihara Y (1993) Stable isotopic structure of aquatic ecosystems. J Biosci 18:483-499

Wotton RS (1990) Particulate and dissolved organic material as food. In: Wotton RS (ed) The biology of particles in aquatic systems. CRC Press, Boston, p 213-261

Zottoli RA (1983) Amphysamytha galapagensis, a new species of ampharetid polychaete from the vicinity of abyssal hydrothermal vents in the Galapagos Rift and the role of this species in rift ecosystems. Proc Biol Soc Wash 95: $48-57$

Submitted: February 22, 2002; Accepted: September 24, 2002 Proofs received from author(s): December 5, 2002 